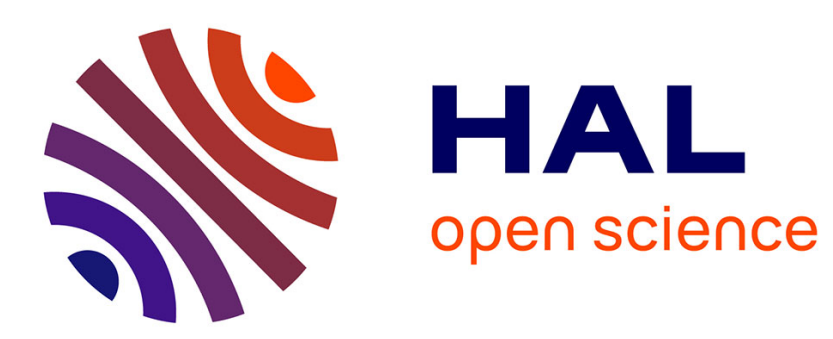

\title{
Variability of Botrytis cinerea sensitivity to pyrrolnitrin, an antibiotic produced by biological control agents.
}

Sakhr Ajouz, Anne Sophie A. S. Walker, Frédéric F. Fabre, Pierre Leroux, Philippe C. Nicot, Marc Bardin

\section{- To cite this version:}

Sakhr Ajouz, Anne Sophie A. S. Walker, Frédéric F. Fabre, Pierre Leroux, Philippe C. Nicot, et al.. Variability of Botrytis cinerea sensitivity to pyrrolnitrin, an antibiotic produced by biological control agents.. BioControl, 2011, 56, pp.353-363. 10.1007/s10526-010-9333-7 . hal-01000474

\section{HAL Id: hal-01000474 \\ https://hal.science/hal-01000474}

Submitted on 29 May 2020

HAL is a multi-disciplinary open access archive for the deposit and dissemination of scientific research documents, whether they are published or not. The documents may come from teaching and research institutions in France or abroad, or from public or private research centers.
L'archive ouverte pluridisciplinaire HAL, est destinée au dépôt et à la diffusion de documents scientifiques de niveau recherche, publiés ou non, émanant des établissements d'enseignement et de recherche français ou étrangers, des laboratoires publics ou privés. 


\title{
Variability of Botrytis cinerea sensitivity to pyrrolnitrin, an antibiotic produced by biological control agents.
}

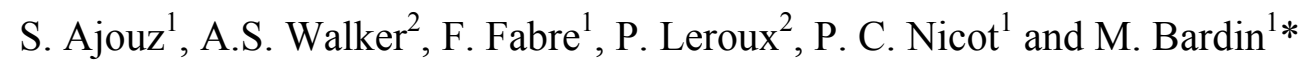 \\ ${ }^{1}$ INRA, UR407, Plant Pathology Unit, Domaine St Maurice, F-84140 Montfavet, France \\ 2 INRA UMR 1290, Bioger-CPP, Route de St Cyr, F-78026 Versailles cedex, France.
}

* Corresponding author. Mailing address: INRA, UR407, Unité de Pathologie Végétale, Domaine St Maurice, F-84140 Montfavet, France. Phone: 33-432-72-28-55. Fax: 33-432-72-28-41. E-mail: $\underline{\text { marc.bardin@avignon.inra.fr }}$

Short title: Baseline sensitivity of Botrytis cinerea to pyrrolnitrin

\begin{abstract}
To establish a baseline sensitivity of Botrytis cinerea to pyrrolnitrin, an antibiotic produced by several biological control agents, 204 isolates were tested for sensitivity to pyrrolnitrin using a spore germination assay. The results showed that the isolates exhibited a wide range of sensitivity to pyrrolnitrin, with an 8.4-fold difference in $\mathrm{EC}_{50}$ (effective concentration to reduce spore germination by $50 \%$ comparing to the control) values between the least and the most sensitive isolates. The model-based clustering analysis indicate that the distribution of the $\mathrm{EC}_{50}$ values best fit a normal mixture model with 3 components and unequal variance. The less sensitive isolates were also multidrug resistant isolates. The efficacy of the pyrrolnitrin-producing Pseudomonas chlororaphis $\mathrm{ChPhzS} 24$ strain was tested in vitro and on tomato plants with isolates of $B$. cinerea having different $\mathrm{EC}_{50}$ values. Whatever the $\mathrm{EC}_{50}$ value of the isolates tested, no significant differences in sensitivity were observed towards this bacterium indicating an absence of resistance to this biological control agent within $B$. cinerea isolates and suggesting also that additional mechanisms of action are probably operated by this biological control agent.
\end{abstract}

Keywords biological control, durability, baseline, multiple-drug-resistance, aggressiveness 
Version définitive du manuscrit publié dans / Final version of the manuscript published in :BioControl, 2011, 56, 353-363. DOI: 10.1007/s10526-010-9333-7. The original publication is available at www.springerlink.com.

\section{Introduction}

Gray mould, caused by the fungus Botrytis cinerea Pers.:Fr (teleomorph Botryotinia fuckeliana (de Bary) Whetzel), is a severe disease on a wide range of economical importance crops. Chemical control remains the main measure to reduce the incidence of this pathogen in most crops but resistance of $B$. cinerea to most fungicides has been reported worldwide (Leroux 2004). The development of biological control methods may be a good complement to control the disease and many biological control agents have been described in the past years (Boff et al. 2002; Elad et al. 1998; Elmer and Reglinski 2006; Helbig 2002; Utkhede and Mathur 2006). Mechanisms involved in the biological control include hyperparasitism, induction of plant-host resistance, competition for nutrients, or production of inhibitory metabolites (Elad and Stewart 2004). Several bacteria, such as Enterobacter agglomerans, Serratia spp. or Pseudomonas spp., described as potential biological control agents against $B$. cinerea produce the antibiotic pyrrolnitrin (3-chloro-4-(2' -nitro-3' chlorophenyl)-pyrrole) (Chernin et al. 1996; Janisiewicz and Roitman 1988; Raaijmakers et al. 2002). This antibiotic has been reported to inhibit the growth of B. cinerea (Hammer et al. 1993). A recurring problem encountered in the field with biological control against plant pathogens is the inconsistency of its efficacy (Elad and Stewart 2004). According to Elad and Stewart (2004), this can be attributed to climatic variations encountered in field conditions, a lack of ecological competence of the biological control agents, and/or an unstable quality of the products. However, reduction of efficacy may also result from the variability of sensitivity of plant pathogens to biological control agents.

The build-up of field resistance to biological control agents could arise if plant pathogens have the ability to produce natural mutants with reduced susceptibility under the selection pressure of products used by farmers. For instance, Li and Leifert (1994) have shown that after 10 successive treatments on plants, the efficacy of the antibiotic-producing bacterium Bacillus subtilis CL27 against B. cinerea dropped dramatically (Li and Leifert 1994). Recently, Ajouz et al. (2010) have demonstrated that $B$. cinerea can become less sensitive to the antibiotic pyrrolnitrin. This resistance makes the pathogen less sensitive to a pyrrolnitrin-producing bacterium in in vitro tests (Ajouz et al. 2010). Possible loss of efficacy of a biological control agent could also result from the selection of pre-existing plant pathogen isolates with low susceptibility in natural populations. Schouten et al. (2004) have for example observed that $17 \%$ of the strains of Fusarium oxysporum were 'naturally' tolerant to the antibiotic 2,4 diacetylphloroglucinol (2,4 DAPG). A recent study has shown that $B$. cinerea can tolerate the antibiotic 2,4 DAPG produced by the bacteria Pseudomonas spp. (Schouten et al. 2008). Accordingly, despite the commonly reported assumption that resistance of plant pathogens to biological control agents will develop less frequently as compared to chemical control methods (Duffy et al. 2003), one might fear a possible repercussion on the durability of efficacy of antibiotic-producing biological control agents. In this context, estimating the potential development of resistance to biological control agents will undoubtedly lead to improve resistance management strategies.

The main purposes of this work were (i) to establish a baseline sensitivity distribution of $B$. cinerea to pyrrolnitrin in order to monitor future shifts of this parameter and (ii) to assess the possible risk of resistance to a pyrrolnitrin-producing biological control bacterium. Additional objectives were to investigate if the resistance to pyrrolnitrin within $B$. cinerea isolates has an effect on their level of aggressiveness on tomato and if a cross-resistance between pyrrolnitrin and other fungicides can be detected.

\section{Materials and methods}

\section{Collection and maintenance of Botrytis cinerea isolates}

Two hundred and four isolates of $B$. cinerea were used in this study. These isolates have a wide diversity regarding year and region of isolation, plant hosts or substrate of origin. All these isolates 
were collected from 1987 to 2008 with a majority acquired after 2000 (125 isolates). Regarding their geographical origin, 192 isolates (94\%) were sampled from France, of which 168 were from the southern and 24 from the northern part of the country. In addition, 6 isolates came from Italy, 5 from Syria and one from Portugal. Regarding their substrate of origin, 163 isolates (80\%) were collected from various diseased-plant: 81 from tomato, 56 from grape, 5 from rose, 4 from cucumber, 3 from strawberry, and one isolate from each of the following plant species, artichoke, pepper, carrot, onion, asparagus, peach fruit, cherry fruit, kiwifruit, basil, hydrangea, gerbera, primrose, cyclamen and poinsettia. Forty one isolates were not sampled from diseased plants; they were collected from the air (28 isolates), bird feathers (7), rainwater (3), snow (2) and plant debris (1). All these isolates were single-spored and maintained in stock cultures stored at $-20^{\circ} \mathrm{C}$ in a phosphate buffer $0.06 \mathrm{M}$ containing $20 \%(\mathrm{~V} / \mathrm{V})$ of glycerol.

Inoculum production

Inoculum of B. cinerea was produced in Petri dishes on Potato Dextrose Agar medium (PDA $39 \mathrm{~g} \mathrm{l}^{-}$ 1. Difco Laboratory, Detroit, Michigan) incubated under cool white fluorescent light (14-hour photoperiod $-65 \mu$ mole $\left.\mathrm{m}^{-2} \mathrm{~s}^{-1}\right)$ in a growth chamber at $21^{\circ} \mathrm{C}(14 \mathrm{~h}$ day and $10 \mathrm{~h} \mathrm{night})$. Spores were collected in $5 \mathrm{ml}$ of water on 14-day-old cultures. The spore suspensions were vortexed with glass beads ( $2.5 \mathrm{~mm}$ diameter) to separate the spores and then filtered through $30 \mu \mathrm{m}$ mesh filters to remove mycelial fragments. The final concentration of the suspensions was adjusted to $10^{6}$ spores $\mathrm{ml}^{-1}$ with the aid of a hemacytometer.

\section{Determination of pyrrolnitrin sensitivity}

The effect of pyrrolnitrin (purified microbial pyrrolnitrin $>98 \%$ from Pseudomonas cepacia, Sigma chemical, Israel) was tested on spore germination. A stock solution was prepared by dissolving the antibiotic in methanol at a concentration of $1 \mathrm{mg} \mathrm{ml}^{-1}$ and stored at $4{ }^{\circ} \mathrm{C}$ in the dark to preserve its activity. Pyrrolnitrin was added at different concentrations from 0 to $500 \mu \mathrm{g}^{-1}$ to Glucose Agar medium (GA) containing $10 \mathrm{~g} \mathrm{l}^{-1}$ glucose and $12.5 \mathrm{~g} \mathrm{l}^{-1}$ agar. To evaluate spore germination, $100 \mu \mathrm{l}$ of a suspension at $10^{5}$ spores $\mathrm{ml}^{-1}$ was spread on the surface of a plate. The germination rate was determined by examining 100 spores after 24 hours of incubation at $21^{\circ} \mathrm{C}$. For a given concentration of pyrrolnitrin, three replicates were realized. A spore was considered as germinated if its germ tube was at least as long as its length. The whole experiment was carried out three times independently.

The $50 \%$ effective concentration $\left(\mathrm{EC}_{50}\right)$ was estimated as previously described (Leroux et al. 1999), using the regression curves obtained by graphically plotting the germination rate 24 hours after inoculation against the log-transformed values of the antibiotic concentrations. In the following, analyses were done for each $B$. cinerea isolate on the mean of the $\mathrm{EC}_{50}$ values as derived from the 3 independent repetitions of the test. A Kruskall-Wallis nonparametric test realized with Statistica Kernel version 5.5 software (Statsoft Inc., Tulsa, AZ, USA) was used to test the effect of $B$. cinerea origin on the sensitivity to pyrrolnitrin. To do so, the isolates collected from different substrates were clustered into 4 groups of origin (tomato, grape, other host plants and other substrates). A resistance factor (RF) was calculated as the ratio of the $\mathrm{EC}_{50}$ value of a given isolate over the $\mathrm{EC}_{50}$ value of the most sensitive isolate. For each isolate, the minimum inhibitory concentration was estimated as the lowest concentration required for a full inhibition of the spore germination.

Analysis of the distribution of the sensitivity to pyrrolnitrin

First, the normality of the distribution of the EC50 values was tested with the Anderson-Darling, Cramer-von Mises and Kolmogorov-Smirnov normality tests using the package "nortest" of the R statistical software (http://www.R-project.org). Next, using the package "mclust" of R, we fit 
several Gaussian mixture models (Fraley and Raftery 2007) to investigate whether the 204 EC50 values arise from a mixture of an unknown number of sub-populations of $B$. cinerea, each subpopulation being normally distributed. For our purpose, two univariate Gaussian mixture models were considered. In the first one, the data are distributed according to a mixture of $\mathrm{k}(1 \leq \mathrm{k} \leq 9)$ Gaussian with equal variance. In the second model, the variances are varying among the $\mathrm{k}$ components. To decide which covariance structure and which number of mixture components $(\mathrm{k})$ best fit the data, the Bayesian Information Criterion (BIC) is used (Schwarz 1978). The larger the value of the BIC, the stronger the evidence for the model and number of clusters are. A standard convention for calibrating BIC differences between alternative models is that differences greater than 10 provide a very strong evidence in favour of the model with the larger value.

\section{Effect of pyrrolnitrin on germ tube elongation and on spore production}

The activity of pyrrolnitrin was tested on germ tube elongation and spore production for 8 isolates of $B$. cinerea with $\mathrm{EC}_{50}$ values for spore germination varying from the most sensitive to the less sensitive. Pyrrolnitrin was added at the same concentrations as described above, to GA medium to estimate germ tube elongation and to PDA medium to measure spore production. Germ-tube length $(\mu \mathrm{m})$ was measured with the help of a microscope 48 hours after inoculation, using an image analyzing software (Visiolab1000, BIOCOM S.A, Paris, France). The inoculated plates were incubated at $21^{\circ} \mathrm{C}$ in the dark. The average germ-tube elongation was determined by measuring 20 to 30 germ tubes from arbitrarily-selected germinated spores for each of three independent replicates of the test. Spore production was determined 14 days after inoculation on the same plates. Spores were scrapped from the media, suspended in water and spore concentration was determined using a hemacytometer. Three plates were inoculated for each isolate and the whole experiment was repeated three times. For each isolate, the $\mathrm{EC}_{50} \mathrm{~s}$ were estimated for germ tube elongation and for spore production with the same method as described above for the germination test.

To test the hypothesis that the $\mathrm{EC}_{50}$ values calculated on the basis of the germ-tube elongation and the sporulation were identical between the different isolates of $B$. cinerea, a oneway analysis of variance was performed using the ANOVA module of Statistica software. The multiple comparison test of Student-Newman-Keuls was used to compare the means. The relationships between $\mathrm{EC}_{50}$ values obtained with spore germination and $\mathrm{EC}_{50}$ values obtained with germ-tube elongation and sporulation were assessed by computing the non-parametric Spearman rank coefficient using Statistica software.

\section{Determination of sensitivity to fungicides}

To determine a possible cross-resistance between pyrrolnitrin and chemical fungicides, eight isolates of $B$. cinerea chosen for their various levels of sensitivity to pyrrolnitrin were tested for their levels of sensitivity to 14 fungicides (belonging to 11 different fungicide families) as described by Leroux et al. (1999). The fungicides used were all of technical-grade quality, kindly provided by the companies. For each fungicide, we used the discriminatory inhibition concentrations (Chapeland et al. 1999; Leroux et al. 1999) in order to determine whether or not an isolate was resistant to a fungicide. For a given isolate, the resistance to the different fungicides was tested on three replicate plates using a spore germination test at $21^{\circ} \mathrm{C}$. The whole experiment was conducted three times independently. The relationship between sensitivity of isolates to pyrrolnitrin and to fungicides was examined by comparing the $\mathrm{EC}_{50}$ for pyrrolnitrin to the number of fungicides to which isolates were resistant. The statistical analysis was carried out by computing the non-parametric Spearman rank coefficient using Statistica software.

In vitro interaction between Botrytis cinerea and the pyrrolnitrin-producing bacterium Pseudomonas chlororaphis ChPhzS24 
The antagonistic activity of a pyrrolnitrin-producing bacterium was tested in vitro against fourteen isolates of $B$. cinerea having different $\mathrm{EC}_{50}$ values varying from the most sensitive $\left(\mathrm{EC}_{50}=5.1 \pm\right.$ $\left.0.2 \mu \mathrm{g} \mathrm{l}^{-1}\right)$, to the less sensitive ones $\left(\mathrm{EC}_{50}=31.8 \pm 2.3 \mu \mathrm{g}^{-1}\right)$. We used strain ChPhzS24 of Pseudomonas chlororaphis (Mazurier et al. 2009) which was kindly provided by P. Lemanceau (INRA Dijon, France). This isolate was grown on TSA medium $\left(3 \mathrm{~g}^{-1}\right.$ Tryptic Soy broth and $15 \mathrm{~g}$ $1^{-1}$ Agar) in Petri plates for $48 \mathrm{~h}$ at $25^{\circ} \mathrm{C}$, and cells were harvested in sterile distilled water. The cell density was determined spectrophotometrically at $580 \mathrm{~nm}$ and adjusted to the desired concentration. Confrontation tests were conducted on TSA medium in $90 \mathrm{~mm}$-diameter Petri plates as previously described (Ajouz et al. 2010). In each plate, the fungus (5 mm diameter mycelial plug) and the bacterium $\left(20 \mu \mathrm{l}\right.$ droplet dosed at $\left.10^{7} \mathrm{CFU} \mathrm{ml}{ }^{-1}\right)$ were placed $25 \mathrm{~mm}$ apart. In control plates, a droplet of sterile distilled water was used instead of the bacterial suspension. Three replicate plates were inoculated for each test and incubated at $21^{\circ} \mathrm{C}$ in the dark. The whole experiment was conducted three times independently. For each test, the width of the inhibition zone was measured daily for five days after inoculation. Additionally, mycelial growth (radius in $\mathrm{mm}$ ) was measured and the inhibition of mycelial growth was assessed with an index computed as [1- (radius of mycelial growth on control plates / radius of mycelial growth in presence of the bacterium)] x100.

The levels of sensitivity of the $14 \mathrm{~B}$. cinerea isolates to the bacterium $P$. chlororaphis were compared using the ANOVA module of Statistica software. In this analysis, the elementary replicate for a given isolate was the average width of the inhibition zone for the three replica plates used in each of the three independent repetitions.

Aggressiveness of Botrytis cinerea isolates and efficacy of biocontrol by Pseudomonas chlororaphis ChPhzS24 on tomato plants

The level of aggressiveness and the efficacy of Pseudomonas chlororaphis ChPhzS24 to control the fungal pathogen were tested with isolates of $B$. cinerea having various level of sensitivity to pyrrolnitrin. Aggressiveness was estimated for 14 isolates and protection of tomato with the bacterium was tested for 7 isolates. These seven isolates were chosen based on their various level of resistance to pyrrolnitrin $\left(\mathrm{EC}_{50}\right.$ values from $7.0 \pm 0.3 \mu \mathrm{g} \mathrm{l^{-1 }}$ to $31.8 \pm 2.3 \mu \mathrm{g} \mathrm{l^{-1 }}$ ). The tests were done on 2-month old tomato plants cv. Monalbo (INRA, Avignon, France) as previously described (Bardin et al. 2008). To this end, three leaves per plant were removed leaving 5-10 mm petiole stubs on the stems and each pruning wound was inoculated with $10 \mu \mathrm{l}$ of a spore suspension of $B$. cinerea dosed at $10^{6}$ spores $\mathrm{ml}^{-1}$. The pathogen was inoculated alone as a control and to measure its aggressiveness. It was inoculated together with $P$. chlororaphis $\mathrm{ChPhzS} 24$ to test the efficacy of the pyrrolnitrin-producing bacterium against $B$. cinerea. The bacterium was applied to pruning wounds as $10 \mu \mathrm{l}$ aliquots of a cell suspension dosed at $10^{8} \mathrm{CFU} \mathrm{ml}{ }^{-1}, 5$ minutes after the inoculation of $B$. cinerea. The lengths of resulting stem lesions were monitored daily for 7 days after inoculation. All plants were incubated in a growth chamber with a photoperiod of 14 hours and maintained at $21^{\circ} \mathrm{C}$ with a relative humidity above $80 \%$. The experiment was repeated three times independently, each with three replicate plants per treatment. To take into account the kinetics of disease development, we computed an average area under the disease progress curve (AUDPC) for each isolate as described previously (Decognet et al. 2009). To facilitate the comparison of aggressiveness among isolates, a relative aggressiveness index (in percent) was computed as the ratio between the average AUDPC of the tested isolate and that of reference isolate $\mathrm{BC}$, multiplied by 100 . The AUDPC values were used to calculate a protection index as: $\left[100 \mathrm{x}\left(\mathrm{AUDPC}_{\text {control }}\right.\right.$ $\left.\mathrm{AUDPC}_{\text {bacterial treatment }} / \mathrm{AUDPC}_{\text {control }}\right)$ ], where $\mathrm{AUDPC}_{\text {control }}$ represented the plants inoculated with $B$.

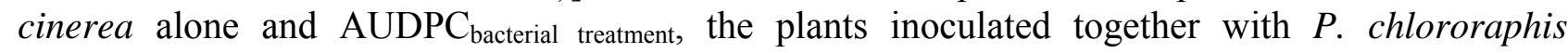
ChPhzS24.

The levels of sensitivity of $B$. cinerea isolates to $P$. chlororaphis between isolates were compared using the ANOVA module of Statistica software. In this analysis, the elementary replicate for a given isolate was the average protection index for the three replica plants used in each of the three independent repetitions. To test the hypothesis that the level of aggressiveness of 
an isolate was independent from its level of resistance to pyrrolnitrin, statistical analyses were performed using the ANOVA module of Statistica software, and the multiple comparison test of Student-Newman-Keuls was used to compare the means of the aggressiveness index values. The relationship between sensitivity to pyrrolnitrin and aggressiveness on tomato plants was assessed by computing the non-parametric Spearman rank coefficient using Statistica software.

\section{Results}

\section{Effect of pyrrolnitrin on spore germination of $B$. cinerea}

Two hundred and four field-collected $B$. cinerea isolates were tested for their sensitivity to pyrrolnitrin. The $\mathrm{EC}_{50}$ values based on spore germination rate ranged from 3.8 to $31.8 \mu \mathrm{g}^{-1}$ and most isolates (52\%) had an $\mathrm{EC}_{50}$ below $10 \mu \mathrm{g} \mathrm{l^{-1 }}$ (Fig. 1). Significant differences in sensitivity to pyrrolnitrin were detected between isolates (ANOVA on $\mathrm{EC}_{50}$ values, $\boldsymbol{F}_{203,567}=9, P<0.0001$ ). The least sensitive isolate was separated from the most sensitive isolate by a resistance factor of 8.4. None of the 204 isolates were able to germinate on medium amended with $100 \mu \mathrm{g}^{-1}$ pyrrolnitrin. No significant differences of mean sensitivity to pyrrolnitrin (based on mean $\mathrm{EC}_{50}$ values) were observed between different groups of isolates of $B$. cinerea coming from the different hosts, tomato, grape, other plants and non plant (ANOVA, $\left.\boldsymbol{F}_{3,200}=0.28, P=0.84\right)$ (Table 1). The Kruskall-Wallis nonparametric test indicates that the medians are not significantly different $(H=6.7, d f=3, P=$ $0.08)$.

The distribution of the pyrrolnitrin $\mathrm{EC}_{50}$ values of the 204 isolates is showed in figure 1 . Normality tests indicate that $\mathrm{EC}_{50}$ data are not normally distributed (Anderson-Darling $P=1.8 .10^{-}$ 11, Cramer-von Mises $P=3 \cdot 3 \cdot 10^{-7}$, Kolmogorov-Smirnov $P=4.3 \cdot 10^{-5}$ ). The normal mixture modelling analysis strongly supports the presence of 3 sub-populations in the distribution of the $\mathrm{EC}_{50}$ values. Indeed the model that best fit the data is a normal mixture model with 3 components of unequal variances. The difference between its BIC (-1107) and the second best BIC (-1118) obtained for a model with 2 components of equal variance is greater than 10 . This provides a very strong evidence in favor of the model with 3 components: the first sub-population regrouped 35\% of the isolates with a mean $\mathrm{EC}_{50}$ of $6 \mu \mathrm{g} \mathrm{l}^{-1}$ and a standard deviation of 1.1, the second one regrouped $62 \%$ of the isolates with a mean $\mathrm{EC}_{50}$ of $11 \mu \mathrm{g} \mathrm{l}^{-1}(\sigma=2.6)$ and the last component regrouped only $3 \%$ of the isolates with a mean $\mathrm{EC}_{50}$ of $26 \mu \mathrm{g}^{-1}(\sigma=4)$.

Minimum inhibitory concentrations were defined for each isolate tested in this study. These concentrations were similar, ca. 20-30 $\mathrm{g} \mathrm{l}^{-1}$, between to the first two components of the population, which could be qualified as sensitive. The minimum inhibitory concentration was higher for the third component of the population, ca. 50-100 $\mathrm{g}^{-1}$. Based on these results, discriminatory doses of pyrrolnitrin can be defined as ca. $30 \mu \mathrm{g}^{-1}$ to differentiate sensitive from moderate resistant isolates, and $100 \mu \mathrm{g}^{-1}$ to determine the highly resistant isolates.

\section{Effect of pyrrolnitrin on germ-tube elongation and on spore production of $B$. cinerea}

To test the effect of pyrrolnitrin on germ-tube elongation and on spore production, the in vitro inhibitory action of pyrrolnitrin was tested on 8 isolates of $B$. cinerea having various level of sensitivity to pyrrolnitrin based on spore germination tests. Significant differences between the 8 isolates tested were observed for the germ tube elongation and the sporulation (ANOVA on $\mathrm{EC}_{50}$ values, $F_{7,11}=7.6, P=0.002$ and $F_{7,9}=39, P=5 \times 10^{-6}$, respectively, Table 2$)$. Moreover, a significant correlation was observed between $\mathrm{EC}_{50}$ values obtained for spore germination and $\mathrm{EC}_{50}$ values obtained for spore production $\left(\mathrm{R}_{\text {spearman }}=0.79, P=0.02\right)$. However, the correlation between $\mathrm{EC}_{50}$ values for germination and $\mathrm{EC}_{50}$ values for germ-tube elongation was not statistically significant $\left(\mathrm{R}_{\text {spearman }}=0.65, P=0.08\right)$. Spore germination, germ-tube elongation, and sporulation of the 8 isolates were completely inhibited at $100 \mu \mathrm{g} \mathrm{l}^{-1}$.

The three less sensitive isolates to pyrrolnitrin based on spore germination have an $\mathrm{EC}_{50}$ based on sporulation, 6 to 13.6 times higher than the most sensitive isolate tested (Table 2). 
Version définitive du manuscrit publié dans / Final version of the manuscript published in :BioControl, 2011, 56, 353-363. DOI: 10.1007/s10526-010-9333-7. The original publication is available at www.springerlink.com.

Moreover, they are able to produce nearly 12.6 times more spores than the most sensitive isolate tested on $10 \mu \mathrm{g} \mathrm{l}^{-1}$ pyrrolnitrin.

Relationship between sensitivity to pyrrolnitrin and aggressiveness of isolates on tomato plants

To assess the relationship between the $\mathrm{EC}_{50}$ values to pyrrolnitrin and the level of aggressiveness on tomato plants, 14 isolates of $B$. cinerea having different $\mathrm{EC}_{50}$ values on pyrrolnitrin were tested. Infection of pruning wounds and development of stem lesions was observed for 12 out of 14 isolates tested. Significant differences in the level of aggressiveness on tomato plant of $B$. cinerea isolates were observed (ANOVA, $F_{13,28}=18.7, P=2 \times 10^{-10}$; Table 3). However, no evidence of correlation between $\mathrm{EC}_{50}$ values to pyrrolnitrin and index of aggressiveness on tomato was observed $\left(\mathrm{R}_{\text {spearman }}=-0.14, P=0.64\right)$.

Protection of tomato against B. cinerea with the pyrrolnitrin-producing P. chlororaphis ChPhzS24 strain

Seven isolates of $B$. cinerea having various levels of sensitivity to pyrrolnitrin were tested on tomato plants to estimate the efficacy of the pyrrolnitrin-producing P. chlororaphis ChPhzS24 strain on tomato plants. The efficacy of protection of tomato by the bacterium was high as the protection indices were comprised between $97.1 \%$ and $100 \%$ (Table 3 ). The protection indices were not significantly different between the 7 isolates whatever their $\mathrm{EC}_{50}$ values $\left(\mathrm{ANOVA}, F_{6,14}=\right.$ $2.1, P=0.12$, Table 3 ). The average protection index for the 7 isolates tested was $98.8 \pm 0.4 \%$.

In vitro sensitivity of $B$. cinerea mycelial growth to the pyrrolnitrin-producing $P$. chlororaphis ChPhzS24 strain

The inhibitory activity of the pyrrolnitrin-producing bacterial strain P. chlororaphis ChPhzS24 was tested on mycelial growth in vitro on 14 isolates of $B$. cinerea differing in their level of sensitivity to pyrrolnitrin for spore germination. All isolates displayed a similar level of sensitivity to the bacterium, measured by the inhibition zone, whatever their $\mathrm{EC}_{50}$ values for spore germination (ANOVA, $F_{13,27}=0.68, P=0.77$, Table 3 ). The mean inhibition zone between the bacteria and the pathogen is $16.8 \pm 0.4 \mathrm{~mm}$ for all the $B$. cinerea isolates tested. The bacterium reduces the radial mycelial growth of the pathogen fungus with a mean growth inhibition of $71.5 \pm 0.9 \%$.

\section{Relationship between sensitivity to pyrrolnitrin and to fungicides}

Eight isolates of $B$. cinerea differing in their $\mathrm{EC}_{50}$ values for pyrrolnitrin inhibition of spore germination were tested for their sensitivity to 14 fungicides belonging to 11 fungicide families. Different patterns of sensitivity to fungicides were observed (Table 4). The three least sensitive isolates to pyrrolnitrin were resistant to 7 out of the 11 fungicide families tested, suggesting that they are multiple-drug-resistant (MDR). Among the five other isolates tested, three patterns of fungicide resistance were detected. Isolates $\mathrm{BC} 1$ and $\mathrm{BC} 26$ were both resistant to the same 5 fungicide families. Isolates $\mathrm{BC} 21, \mathrm{BC} 25$ and $\mathrm{H} 6$ were resistant to 3 fungicide families only. A significant correlation was observed between the level of sensitivity to pyrrolnitrin ( $\mathrm{EC}_{50}$ values) and the number of fungicides to which the isolates were resistant $\left(\mathrm{R}_{\text {spearman }}=0.88, P=0.004\right)$.

\section{Discussion}

Historically, much effort has been devoted to the study of the efficacy of the antibiotic pyrrolnitrin and of pyrrolnitrin-producing biological control agents to control $B$. cinerea on plants or fruits (Chernin et al. 1996; Janisiewicz et al. 1991; Janisiewicz and Roitman 1988). In contrast, the study of sensitivity distribution of natural isolates of $B$. cinerea to pyrrolnitrin is lacking. The evaluation 
of 204 isolates in the present study revealed that they were not equally affected by this antibiotic. Indeed, B. cinerea exhibited a large range of sensitivity to pyrrolnitrin based on spore germination, with 8.4-fold differences in $\mathrm{EC}_{50}$ values between the least and the most sensitive isolates. The existence of this important range of sensitivity reflects the fact that this $B$. cinerea population of isolates consists of a mixture of 3 sub-populations varying in their sensitivity to pyrrolnitrin and reveals the presence of resistant isolates in the field. However, despite this diversity, a similarly high level of sensitivity to the pyrrolnitrin-producing bacterium P. chlororaphis ChPhzS24 was observed in vitro and on tomato plants for all isolates tested. A possible explanation for this phenomenon may be related to the concentration of pyrrolnitrin produced by the bacterium and present in the vicinity of the fungus in the medium or in the plant tissue. Although the quantity of pyrrolnitrin produced by strain ChPhzS24 of $P$. chlororaphis is not known, one may hypothesise that resulting concentrations could be greater than those used to determine the baseline sensitivity of $B$. cinerea to pyrrolnitrin in vitro. Another explanation could be that isolates of $B$. cinerea were potentially sensitive to phenazine-1-carboxylic acid, an antibiotic possibly also produced by $P$. chlororaphis (Mazurier et al. 2009; Schoonbeek et al. 2002). Finally, one can not eliminate the hypothesis that apart from additional antibiotics production other mechanisms of action may be implicated (like cell-to-cell interference or competition for nutrients) in the effectiveness of the bacterium against $B$. cinerea in the tomato plant assay. Nevertheless, these results suggest that the current population of $B$. cinerea may be effectively controlled by this pyrrolnitrin-producing biological control agent.

In a previous study, levels of resistance to pyrrolnitrin higher than those detected in this study were observed in B. cinerea (Ajouz et al. 2010). Thus, an experimental evolution study done with pyrrolnitrin-sensitive isolates provides evidence that $B$. cinerea is able to gradually build-up resistance to high concentrations of pyrrolnitrin and subsequently to become less sensitive to a pyrrolnitrin-producing biological control agent in vitro (Ajouz et al. 2010). A question arising from these experiments would be whether the moderate level of resistance to pyrrolnitrin observed for some isolates of $B$. cinerea in the present study facilitates the acquisition of a higher level of resistance to the antibiotic and therefore to pyrrolnitrin-producing biological control agents. Therefore, it would be particularly interesting to compare the rate of evolution of resistance to pyrrolnitrin of the sensitive isolates to the rate of evolution of resistance to pyrrolnitrin of the less sensitive isolates detected in this study, under the selective pressure exerted by the antibiotic.

The six isolates that were significantly less sensitive to the antibiotic were all collected from fungicides-treated vineyard in Champagne and were classified as MDR isolates. This study leads to speculation whether MDR isolates would be systematically resistant to pyrrolnitrin. Work done by Schoonbeek et al. (2002) revealed that some broad-spectrum antibiotics produced by Pseudomonas spp. induced expression of several ATP-binding cassette (ABC) transporter genes in B. cinerea (Schoonbeek et al. 2002). These ABC transporters are involved in the multiple-drug-resistance and affect the sensitivity of $B$. cinerea to fungicides and to various natural toxic metabolites (De Waard 1997; De Waard et al. 2006; Schoonbeek et al. 2001). However, recent results suggest a certain selectivity of ABC transporters (De Waard et al. 2006; Kretschmer et al. 2009; Schoonbeek et al. 2002). More work is needed to determine the exact relationship between the resistance to fungicides and to pyrrolnitrin and the role of $\mathrm{ABC}$ transporters in the resistance of $B$. cinerea to this antibiotic. This work would be of great interest to understand how B. cinerea acquired a resistance to pyrrolnitrin, while pyrrolnitrin-producing biological control agents were never used in the field in the regions of collection of the isolates tested in this study. One interesting issue would be to determine the possible effect of fungicide treatments on the development of resistance to this antibiotic.

Another possible hypothesis to explain how B. cinerea acquired a resistance to pyrrolnitrin is related to the fact that this fungus can survive in various environments, such as soil for instance (Jarvis 1977). Pyrrolnitrin production is a widely distributed trait among different bacterial genera that are ubiquitous in soil and plant-associated environments (Garbeva et al. 2004; Raaijmakers et 
al. 2002). Therefore, as a saprobe, B. cinerea may have occasional encounters with pyrrolnitrinproducing microorganisms and thus the possibility to develop resistance to this antibiotic.

Finally, the impact of the sub-population of $B$. cinerea resistant to pyrrolnitrin on the effectiveness of pyrrolnitrin-producing biological control agents deserves further attention in field conditions. In commercial vineyards, MDR populations confer selective advantage to B. cinerea in fungicide-treated vineyards (Kretschmer et al. 2009). An interesting point would be to assess whether the resistance to pyrrolnitrin observed for some isolates in this study enables them to confer a selective advantage in the presence of the pyrrolnitrin-producing biological control agent. The establishment of the baseline sensitivity and of the discriminatory concentrations to pyrrolnitrin would be helpful in future studies aiming at monitoring possible shifts in the sensitivity to pyrrolnitrin-producing biological control agents in B. cinerea populations.

Acknowledgements The authors grateful acknowledge Claire Troulet and Gisèle Riqueau for excellent technical assistance and Véronique Decognet and Christel Leyronas for providing isolates of Botrytis cinerea. This work was partly supported by the French National Research Agency (ANR-ADD ECOSERRE project). S.A. received a grant from the Syrian government to complete postgraduate studies.

\section{References}

Ajouz S, Nicot PC, Bardin M (2010) Adaptation to pyrrolnitrin in Botrytis cinerea and cost of resistance. Plant Pathol 59:556-566

Bardin M, Fargues J, Nicot PC (2008) Compatibility between biopesticides used to control grey mould, powdery mildew and whitefly on tomato. Biol Control 46:476-483

Boff P, Köhl J, Gerlagh M, de Kraker J (2002) Biocontrol of grey mould by Ulocladium atrum applied at different flower and fruit stages of strawberry. BioControl 47:193-206

Chapeland F, Fritz R, Lanen C, Gredt M, Leroux P (1999) Inheritance and mechanisms of resistance to anilinopyrimidine fungicides in Botrytis cinerea (Botryotinia fuckeliana). Pestic Biochem Physiol 64:85-100

Chernin L, Brandis A, Ismailov Z, Chet I (1996) Pyrrolnitrin production by an Enterobacter agglomerans strain with a broad spectrum of antagonistic activity towards fungal and bacterial phytopathogens. Curr Microbiol 32:208-212

De Waard MA (1997) Significance of ABC transporters in fungicide sensitivity and resistance. Pest Sci 51:271-275

De Waard MA, Andrade AC, Hayashi K, Schoonbeek HJ, Stergiopoulos I, Zwiers L-H (2006) Impact of fungal drug transporters on fungicide sensitivity, multidrug resistance and virulence. Pest Manag Sci 62:195-207

Decognet V, Bardin M, Trottin-Caudal Y, Nicot PC (2009) Rapid change in the genetic diversity of Botrytis cinerea populations after the introduction of strains in a tomato glasshouse. Phytopathology 99:185-193

Duffy B, Schouten A, Raaijmakers JM (2003) Pathogen self-defense: mechanisms to counteract microbial antagonism. Annu Rev Phytopathol 41:501-538

Elad Y, Kirshner B, Yehuda N, Sztejnberg A (1998) Management of powdery mildew and gray mould of cucumber by Trichoderma harzianum T39 and Ampelomyces quisqualis AQ10. BioControl 43:241-251

Elad Y, Stewart A (2004) Microbial control of Botrytis spp. In: Elad Y, Williamson B, Tudzynski P, Delen N (eds) Botrytis: Biology, Pathology and Control. Kluwer Academic Press, Dordrecht, The Netherlands, pp 223-241

Elmer PAG, Reglinski T (2006) Biosuppression of Botrytis cinerea in grapes. Plant Pathol 55:155177 
Version définitive du manuscrit publié dans / Final version of the manuscript published in :BioControl, 2011, 56, 353-363. DOI: 10.1007/s10526-010-9333-7. The original publication is available at www.springerlink.com.

Fraley C, Raftery AE (2007) Model-based methods of classification: Using the mclust software in chemometrics. J Stat Soft 18:13

Garbeva P, Voesenek K, van Elsas JD (2004) Quantitative detection and diversity of the pyrrolnitrin biosynthetic locus in soil under different treatments. Soil Biol Biochem 36:14531463

Hammer PE, Evensen KB, Janisiewicz WJ (1993) Postharvest control of Botrytis cinerea on cut flowers with pyrrolnitrin. Plant Dis 77:283-286

Helbig J (2002) Ability of the antagonistic yeast Cryptococcus albidus to control Botrytis cinerea in strawberry. BioControl 47:85-99

Janisiewicz W, Yourman L, Roitman J, Mahoney N (1991) Postharvest control of blue mold and gray mold of apples and pears by dip treatment with pyrrolnitrin, a metabolite of Pseudomonas cepacia. Plant Dis 75:490-494

Janisiewicz WJ, Roitman J (1988) Biological control of blue mold and grey mold on apple and pear with Pseudomonas cepacia. Phytopathology 78:1697-1700

Jarvis RW (1977) Botryotinia and Botrytis species: taxonomy, physiology, and pathogenicity. A guide to the literature. Canada Department of Agriculture, Ottawa, Canada

Kretschmer M, Leroch M, Mosbach A, Walker AS, Fillinger S, Mernke D, Schoonbeek HJ, Pradier JM, Leroux P, De Waard MA, Hahn M (2009) Fungicide-driven evolution and molecular basis of multidrug resistance in field populations of the grey mould fungus Botrytis cinerea. PloS Pathogens 5:e1000696

Leroux P, Chapeland F, Desbrosses D, Gredt M (1999) Patterns of cross-resistance to fungicides in Botryotinia fuckeliana (Botrytis cinerea) isolates from French vineyards. Crop Prot 18:687-697

Leroux P (2004) Chemical control of Botrytis and its resistance to chemical fungicides. In: Elad Y, Williamson B, Tudzynski P, Delen N (eds) Botrytis: Biology, Pathology and Control. Kluwer Academic Press, Dordrecht, The Netherlands, pp 195-222

Li H, Leifert C (1994) Development of resistance in Botryotinia fuckeliana (de Barry) Whetzel against the biological control agent Bacillus subtilis CL27. Z PflKrankh PflSchutz 101:414-418

Mazurier S, Corberand T, Lemanceau P, Raaijmakers JM (2009) Phenazine antibiotics produced by fluorescent pseudomonads contribute to natural soil suppressiveness to Fusarium wilt. The ISME Journal 3:977-991

Raaijmakers JM, Vlami M, Souza JTd (2002) Antibiotic production by bacterial biocontrol agents. Antonie Van Leeuwenhoek 81:537-547

Schoonbeek H, del Sorbo G, de Waard MA (2001) The ABC transporter BcatrB affects the sensitivity of Botrytis cinerea to the phytoalexin resveratrol and the fungicide fenpiclonil. Mol Plant Microb Inter 14:562-571

Schoonbeek H, Raaijmakers JM, Waard MAd (2002) Fungal ABC transporters and microbial interactions in natural environments. Mol Plant Microb Inter 15:1165-1172

Schouten A, Berg Gvd, Edel-Hermann V, Steinberg C, Gautheron N, Alabouvette C, Vos CHd, Lemanceau P, Raaijmakers JM (2004) Defense responses of Fusarium oxysporum to 2,4diacetylphloroglucinol, a broad-spectrum antibiotic produced by Pseudomonas fluorescens. Mol Plant Microb Inter 17:1201-1211

Schouten A, Maksimova O, Cuesta-Arenas Y, van den Berg G, Raaijmakers JM (2008) Involvement of the $\mathrm{ABC}$ transporter BcAtrB and the laccase BcLCC2 in defence of Botrytis cinerea against the broad-spectrum antibiotic 2,4-diacetylphloroglucinol. Environ Microbiol 10:1145-1157

Schwarz G (1978) Estimating the dimension of a model. The Annals of Statistics 6:461-464

Utkhede RS, Mathur S (2006) Preventive and curative biological treatments for control of Botrytis cinerea stem canker of greenhouse tomatoes. BioControl 51:363-373 
Version définitive du manuscrit publié dans / Final version of the manuscript published in :BioControl, 2011, 56, 353-363. DOI: 10.1007/s10526-010-9333-7. The original publication is available at www.springerlink.com.

Fig. 1 Distribution of the sensitivity to the antibiotic pyrrolnitrin of 204 isolates of Botrytis cinerea collected from 1987 to 2008 , based on inhibition of spore germination. The $\mathrm{EC}_{50}$ is the effective concentration of pyrrolnitrin (in $\mu \mathrm{g} \mathrm{l}^{-1}$ ) inhibiting $50 \%$ of the spore germination.

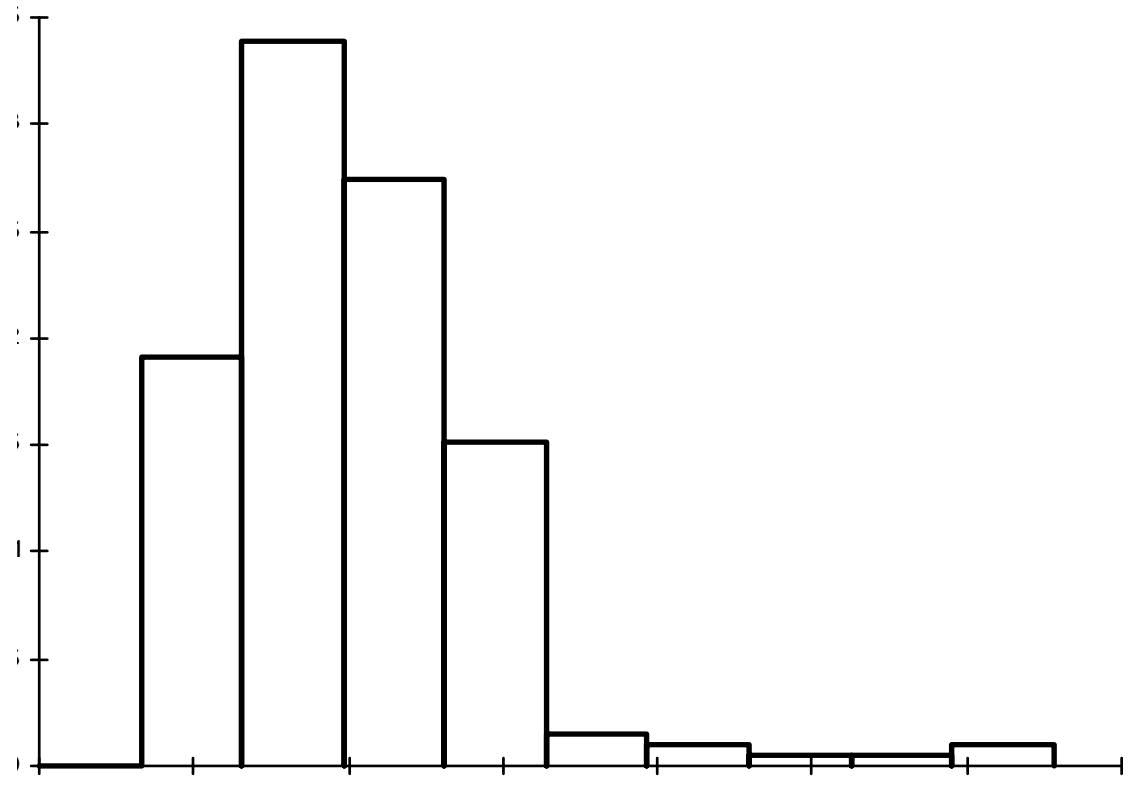




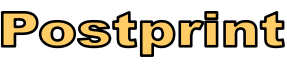

Version définitive du manuscrit publié dans / Final version of the manuscript published in :BioControl, 2011, 56, 353-363. DOI: 10.1007/s10526-010-9333-7. The original publication is available at www.springerlink.com.

Table 1 Sensitivity to pyrrolnitrin based on in vitro inhibition of spore germination of the 204 Botrytis cinerea isolates sampled between 1987 and 2008 and pooled based on their host plants or substrate of origin

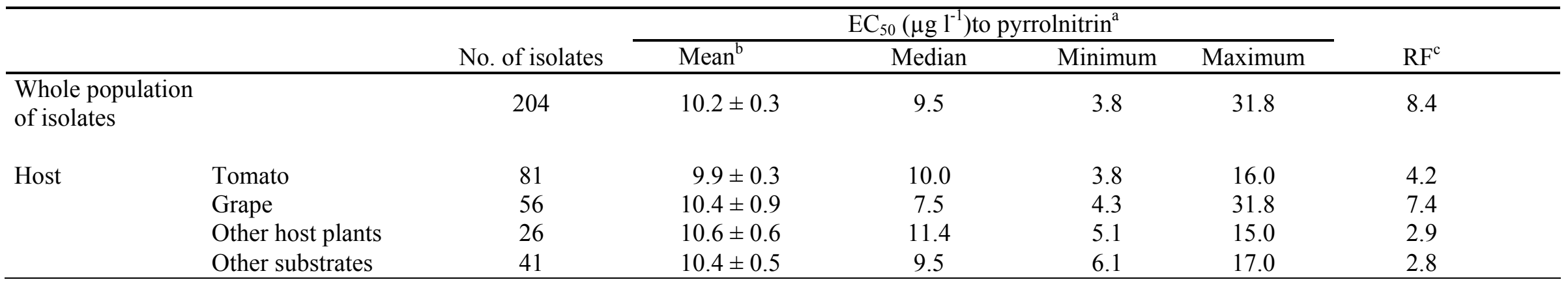

a Values of effective concentration to reduce spore germination by $50 \%$ comparing to the control

b Mean \pm SE for each group of isolates

c Resistance factor computed as the ratio of $\mathrm{EC}_{50}$ of the least sensitive isolate of the considered group of isolates / $\mathrm{EC}_{50}$ of the most sensitive isolate of the considered group of isolates 
Version définitive du manuscrit publié dans / Final version of the manuscript published in :BioControl, 2011, 56, 353-363. DOI: 10.1007/s10526-010-9333-7. The original publication is available at www.springerlink.com.

Table 2 In vitro sensitivity of eight isolates of Botrytis cinerea to pyrrolnitrin based on spore germination, germ-tube elongation and spore production

\begin{tabular}{|c|c|c|c|c|c|c|}
\hline \multirow{3}{*}{$\begin{array}{l}\text { Isolate } \\
05-\mathrm{A}-590\end{array}$} & \multicolumn{6}{|c|}{$\mathrm{Ec}_{50}\left(\mu \mathrm{g} \mathrm{l}^{-1}\right)$ to pyrrolnitrin ${ }^{\mathrm{a}}$} \\
\hline & \multicolumn{2}{|c|}{$\begin{array}{c}\text { Spore } \\
\text { germination }^{\mathrm{b}}\end{array}$} & \multicolumn{2}{|c|}{ Germ-tube length $^{\mathrm{b}}$} & \multicolumn{2}{|l|}{ Sporulation $^{\mathrm{b}}$} \\
\hline & $31.8 \pm 2.3$ & $\mathrm{a}$ & $6.2 \pm 0.2$ & $\mathrm{a}$ & $9.5 \pm 0.5$ & $\mathrm{a}$ \\
\hline 05-A-550 & $27.7 \pm 2.1$ & $\mathrm{~b}$ & $7.1 \pm 0.7$ & $\mathrm{a}$ & $4.2 \pm 0.7$ & $\mathrm{~b}$ \\
\hline $05-\mathrm{A}-587$ & $22.6 \pm 0.3$ & $\mathrm{c}$ & $6.2 \pm 0.6$ & $\mathrm{a}$ & $4.9 \pm 0.4$ & $\mathrm{~b}$ \\
\hline $\mathrm{BC} 26$ & $12.1 \pm 1.2$ & d & $3.8 \pm 0.8$ & $\mathrm{ab}$ & $0.8 \pm 0.2$ & $\mathrm{c}$ \\
\hline H6 & $10.2 \pm 1.2$ & de & $3.6 \pm 1.3$ & $\mathrm{ab}$ & $1.0 \pm 0.1$ & $\mathrm{c}$ \\
\hline $\mathrm{BC} 1$ & $7.0 \pm 0.3$ & e & $4.9 \pm 0.4$ & $\mathrm{ab}$ & $0.7 \pm 0.1$ & $\mathrm{c}$ \\
\hline $\mathrm{BC} 25$ & $5.9 \pm 0.9$ & e & $2.3 \pm 0.3$ & $\mathrm{~b}$ & $2.3 \pm 0.9$ & $\mathrm{c}$ \\
\hline $\mathrm{BC} 21$ & $5.1 \pm 0.2$ & e & $5.9 \pm 1.0$ & $\mathrm{a}$ & $0.7 \pm 0.2$ & $\mathrm{c}$ \\
\hline ANOVA & $\begin{array}{l}F_{7,12}=92.4 \\
P=2 \times 10^{-9}\end{array}$ & & $\begin{array}{l}F_{7,11}=7.6 \\
P=0.002\end{array}$ & & $\begin{array}{r}F_{7,9}=39 \\
P=5 \times 10^{-6}\end{array}$ & \\
\hline Mean $\pm \mathrm{SE}^{\mathrm{c}}$ & $14.2 \pm 1.2$ & & $4.8 \pm 0.3$ & & $2.8 \pm 0.6$ & \\
\hline
\end{tabular}

a Values of effective concentration to reduce spore germination by $50 \%$ comparing to the control

b For each isolate, data are means of three independent repetitions \pm SE. Values within a column followed by the same letter are not significantly different (ANOVA, $\alpha=0.05$; Newman-Keuls test)

c Average values for the eight isolates $\pm \mathrm{SE}$ 
Table 3 Relative aggressiveness of isolates of Botrytis cinerea on tomato plant and effect of the pyrrolnitrin-producing bacterium Pseudomonas chlororaphis $\mathrm{ChPhzS} 24$ in protecting tomato pruning wounds and in inhibiting in vitro mycelial growth of isolates of Botrytis cinerea having different sensitivity level $\left(\mathrm{EC}_{50}\right)$ to pyrrolnitrin.

\begin{tabular}{|c|c|c|c|c|c|}
\hline \multirow[b]{2}{*}{ Isolate } & \multirow{2}{*}{\multicolumn{2}{|c|}{$\begin{array}{l}\text { In vitro } \mathrm{EC}_{50} \text { to } \\
\text { pyrrolnitrin }\left(\mu \mathrm{g}^{-1}\right)^{\mathrm{a}}\end{array}$}} & \multirow[b]{2}{*}{$\begin{array}{c}\text { Relative aggressiveness } \\
\text { index }(\%)^{\mathrm{b}}\end{array}$} & \multicolumn{2}{|c|}{ P. chlororaphis ChPhzS24 } \\
\hline & & & & $\begin{array}{l}\text { Protection } \\
\text { of tomato } \\
\text { plant }(\%)^{c}\end{array}$ & $\begin{array}{c}\text { In vitro } \\
\text { inhibition zone } \\
(\mathrm{mm})^{\mathrm{d}}\end{array}$ \\
\hline $05-A-590$ & $31.8 \pm 2.3$ & $\mathrm{a}$ & $33.7 \pm 7.5 \mathrm{~cd}$ & $100.0 \pm 0.0$ & $15.0 \pm 1.2$ \\
\hline $05-A-550$ & $27.7 \pm 2.1$ & $\mathrm{a}$ & $28.7 \pm 1.8 \mathrm{~cd}$ & $100.0 \pm 0.0$ & $15.0 \pm 1.2$ \\
\hline $05-A-587$ & $22.6 \pm 0.3$ & $\mathrm{~b}$ & $29.0 \pm 5.0 \mathrm{~cd}$ & $100.0 \pm 0.0$ & $17.7 \pm 0.7$ \\
\hline E319 & $14.3 \pm 0.3$ & $\mathrm{c}$ & $63.5 \pm 5.8 \quad b$ & $97.1 \pm 1.3$ & $19.3 \pm 1.3$ \\
\hline E41 & $13.5 \pm 5.0$ & $\mathrm{~cd}$ & $55.2 \pm 8.5 \quad b c$ & $98.0 \pm 1.4$ & $17.5 \pm 2.0$ \\
\hline $\mathrm{BC} 26$ & $12.1 \pm 1.2$ & cde & $10.4 \pm 2.7 \quad \mathrm{de}$ & $-{ }^{\mathrm{e}}$ & $16.6 \pm 1.7$ \\
\hline ВC50 & $12.0 \pm 1.5$ & cde & $32.6 \pm 1.4 \mathrm{~cd}$ & $100.0 \pm 0.0$ & $16.8 \pm 2.2$ \\
\hline E14 & $11.5 \pm 1.6$ & cde & $67.3 \pm 14.3 \quad b$ & - & $17.1 \pm 3.1$ \\
\hline H6 & $10.2 \pm 1.2$ & cde & $0.0 \pm 0.0 \quad \mathrm{e}$ & - & $14.3 \pm 1.9$ \\
\hline $\mathrm{BC} 1$ & $7.0 \pm 0.3$ & de & $100.0 \pm 0.0 \quad \mathrm{a}$ & $98.0 \pm 1.3$ & $16.5 \pm 0.4$ \\
\hline NH-PL3 & $6.4 \pm 0.8$ & de & $119.9 \pm 18.7 \quad \mathrm{a}$ & - & $17.0 \pm 1.7$ \\
\hline NH-OI4 & $6.2 \pm 0.7$ & de & $47.1 \pm 8.2 \quad b c$ & - & $16.3 \pm 3.0$ \\
\hline BC25 & $5.9 \pm 0.9$ & de & $0.0 \pm 0.0 \quad \mathrm{e}$ & - & $19.5 \pm 0.5$ \\
\hline $\mathrm{BC} 21$ & $5.1 \pm 0.2$ & $\mathrm{e}$ & $53.2 \pm 9.1 \quad b c$ & - & $18.3 \pm 1.1$ \\
\hline ANOVA & $\begin{array}{l}F_{13,22}= \\
P=2 \times\end{array}$ & $\begin{array}{l}33.3 \\
10^{-11}\end{array}$ & $\begin{array}{l}F_{13,22}=18.7 \\
P=2 \times 10^{-10}\end{array}$ & $\begin{array}{l}F_{6,14}=2.1 \\
P=0.12\end{array}$ & $\begin{aligned} F_{13,27} & =0.68 \\
P & =0.77\end{aligned}$ \\
\hline
\end{tabular}

Data are means of three independent repetitions \pm standard error of the mean.

a For each isolate, values within a column followed by the same letter are not significantly different (ANOVA, $\alpha=0.05$; Newman-Keuls test).

b Relative aggressiveness index $\left.=100 \mathrm{x}\left(\mathrm{AUDPC}_{\text {isolate }} / \mathrm{AUDPC}_{\mathrm{BC} 1}\right)\right]$ where $\mathrm{AUDPC}_{\mathrm{BC} 1}$ correspond to the plants inoculated with isolate $\mathrm{BC} 1$ and $\mathrm{AUDPC}_{\text {isolate, }}$, the plants inoculated with an other isolate. For each isolate, means within a column followed by the same letter are not significantly different (ANOVA, $\alpha=$ 0.05; Newman-Keuls test).

c Protection of tomato plants by P. chlororaphis ChPhzS24 was calculated as follows [100x (AUDPC control $_{\text {ch }}$ - $\left.\left.\mathrm{AUDPC}_{\text {bacterial treatment }} / \mathrm{AUDPC}_{\text {control }}\right)\right]$ where $\mathrm{AUDPC}_{\text {control }}$ corresponds to the plants inoculated with $B$. cinerea alone and AUDPC ${ }_{\text {bacterial treatment }}$, the plants inoculated together with P. chlororaphis ChPhzS24.

d Zone of inhibition measured in $\mathrm{mm} 5$ days after inoculation.

e $\quad-=$ not done or not relevant 


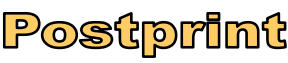

Version définitive du manuscrit publié dans / Final version of the manuscript published in :BioControl, 2011, 56, 353-363. DOI: 10.1007/s10526-010-9333-7. The original publication is available at www.springerlink.com.

Table 4 Pattern of resistance of eight Botrytis cinerea isolates having different sensitivity level $\left(\mathrm{EC}_{50}\right)$ to pyrrolnitrin, to 14 fungicides belonging to 11 chemical families

\begin{tabular}{|c|c|c|c|c|c|c|c|c|c|c|}
\hline & & & $05-\mathrm{A}-590$ & $05-\mathrm{A}-550$ & $05-\mathrm{A}-587$ & $\mathrm{BC} 26$ & H6 & BC1 & $\mathrm{BC} 25$ & $\mathrm{BC} 21$ \\
\hline Pyrrolnitrin $^{\mathrm{a}}$ & $\mathrm{EC}_{50}\left(\mu \mathrm{g} \mathrm{l}^{-1}\right)$ & & $31.8 \mathrm{a}$ & $27.7 \mathrm{~b}$ & $22.6 \mathrm{c}$ & $12.1 \mathrm{~d}$ & $10.2 \mathrm{de}$ & $7.0 \mathrm{e}$ & $5.9 \mathrm{e}$ & $5.1 \mathrm{e}$ \\
\hline \multirow[t]{11}{*}{$\begin{array}{l}\text { Fungicides }{ }^{b} \\
\text { (chemical family) }\end{array}$} & $\begin{array}{l}\text { Iprodione } \\
\text { Procymidone } \\
\text { Vinclozolin }\end{array}$ & (Dicarboximides) & $\mathrm{R}$ & $\mathrm{R}^{\mathrm{e}}$ & $\mathrm{R}$ & $\mathrm{R}$ & $\mathrm{S}$ & $\mathrm{R}$ & $\mathrm{S}$ & $\mathrm{S}$ \\
\hline & $\begin{array}{l}\text { Fenpiclonil } \\
\text { Fludioxonil }\end{array}$ & (Phenylpyrroles) & $\mathrm{R}$ & $\mathrm{R}$ & $\mathrm{S}$ & $\mathrm{S}$ & $\mathrm{S}$ & $\mathrm{S}$ & $\mathrm{S}$ & $\mathrm{S}$ \\
\hline & Dicloran & $\begin{array}{l}\text { (Aromatic } \\
\text { Hydrocarbons) }\end{array}$ & $\mathrm{R}$ & $\mathrm{R}$ & $\mathrm{S}$ & $\mathrm{R}$ & $\mathrm{S}$ & $\mathrm{R}$ & $\mathrm{S}$ & $\mathrm{S}$ \\
\hline & Carbendazim & (Benzimidazoles) & $\mathrm{S}$ & S & $\mathrm{S}$ & $\mathrm{S}$ & $\mathrm{R}$ & $\mathrm{S}$ & $\mathrm{S}$ & $\mathrm{S}$ \\
\hline & Diethofencarb & (N-phenylcarbamates) & $\mathrm{R}$ & $\mathrm{R}$ & $\mathrm{R}$ & $\mathrm{R}$ & $\mathrm{S}$ & $\mathrm{R}$ & $\mathrm{R}$ & $\mathrm{R}$ \\
\hline & Pyrimethanil & (Anilinopyrimidines) & $\mathrm{S}$ & S & $\mathrm{R}$ & $\mathrm{S}$ & S & $\mathrm{S}$ & $\mathrm{S}$ & $\mathrm{S}$ \\
\hline & Prochloraze & (Imidazoles) & $\mathrm{S}$ & S & $\mathrm{R}$ & $\mathrm{S}$ & S & $\mathrm{S}$ & $\mathrm{S}$ & $\mathrm{S}$ \\
\hline & Fenhexamid & (Hydroxyanilides) & $\mathrm{S}$ & $\mathrm{S}$ & $\mathrm{S}$ & $\mathrm{S}$ & $\mathrm{S}$ & $\mathrm{S}$ & $\mathrm{S}$ & $\mathrm{S}$ \\
\hline & Tolnaftate & (Thiocarbamates) & $\mathrm{R}$ & $\mathrm{R}$ & $\mathrm{R}$ & $\mathrm{S}$ & $\mathrm{S}$ & $\mathrm{S}$ & $\mathrm{S}$ & $\mathrm{S}$ \\
\hline & Fenpropidine & (Piperidines) & $\mathrm{R}$ & $\mathrm{R}$ & $\mathrm{R}$ & $\mathrm{R}$ & $\mathrm{R}$ & $\mathrm{R}$ & $\mathrm{R}$ & $\mathrm{R}$ \\
\hline & Cymoxanil & (Cyanooximes) & $\mathrm{R}$ & $\mathrm{R}$ & $\mathrm{R}$ & $\mathrm{R}$ & $\mathrm{R}$ & $\mathrm{R}$ & $\mathrm{R}$ & $\mathrm{R}$ \\
\hline
\end{tabular}

a For each isolate, means within a line followed by the same letter are not significantly different (ANOVA, $\alpha=0.05$; Newman-Keuls test).

b Discriminatory concentrations allowing the classification of isolates in 2 categories, sensitive (S) and resistance (R), were defined by Leroux et al. (1999), as follows: iprodione $2.5 \mu \mathrm{g} \mathrm{ml}^{-1}$, procymidone $10 \mu \mathrm{g} \mathrm{ml}^{-1}$, vinclozolin $5 \mu \mathrm{g} \mathrm{ml}^{-1}$, fenpiclonil $0.5 \mu \mathrm{g} \mathrm{ml}{ }^{-1}$,fludioxonil $0.2 \mu \mathrm{g} \mathrm{ml} \mathrm{m}^{-1}$, dicloran $25 \mu \mathrm{g} \mathrm{ml}{ }^{-1}$, carbendazim $1 \mu \mathrm{g} \mathrm{ml}^{-1}$, diethofencarb $10 \mu \mathrm{g} \mathrm{ml}^{-1}$, pyrimethanil $1 \mu \mathrm{g} \mathrm{ml}{ }^{-1}$, prochloraze $0.25 \mu \mathrm{g} \mathrm{ml}{ }^{-1}$, fenhexamid $0.4 \mu \mathrm{g} \mathrm{ml} l^{-1}$, tolnaftate $10 \mu \mathrm{g} \mathrm{ml}{ }^{-1}$, fenpropidine $0.08 \mu \mathrm{g} \mathrm{ml}^{-1}$, cymoxanil $25 \mu \mathrm{g} \mathrm{ml}^{-1}$. The fungicides used were technical products. 